\title{
パルス法NMRによる最近のゴム研究
}

野口徹*1 $\cdot$ 岩蕗 仁*2

\section{Recent Studies on Crosslinked Rubbers by Pulsed NMR}

Toru NOGUCHI (Nissin Kogyo Co., Ltd., 801 Kazawa, Toubu-machi, Chiisagata-gun, Nagano 389-0514, Japan), Hitoshi IWABUKI (Industrial Technology Center of Okayama Prefecture, 5301 Haga, Okayama 701-1296, Japan)

Pulsed NMR, which is used for measuring spin-spin relaxation time, $\mathrm{T}_{2}$, and spin-lattice relaxation time, $\mathrm{T}_{1}$, has a unique advantage over other techniques because it can provide direct information on molecular motion and volume fraction of each component in the composites ${ }^{1,3), 4), 20), 25), 60)}$. Rubber-Carbon black interactions are very important to study the reinforcement of rubbers. The $\mathrm{T}_{2}$ signal of the bound rubber was resolved into two components, short $\mathrm{T}_{2}$ component and long $\mathrm{T}_{2}$ component. In a two-phase model for interpreting the reinforcement, one phase was the immobilized rubber layer around carbon blacks, and the other was the rubber away from the filler surface ${ }^{1,29), 34), 36), 60)}$. On the other hand, Folland and co-workers ${ }^{3), 4}$ suggested that unfilled isoprene rubber crosslinked by irradiation consisted of two components such as network structures and non-network structures. Recently, Noguchi and co-work$\mathrm{ers}^{48)}$ reported the results from a pulsed NMR spectroscopy with Hahn echo method for EPDM specimens and their relations with the dynamic fatigue behaviors. The retention of stress under fatigue for peroxide-crosslinked EPDM filled with carbon black, calcium-carbonate, or silica, tended to decrease as the network $\mathrm{T}_{2}{ }^{3), 4)}$ became longer and the non-network fraction became larger. This result suggests the relationships between the fatigue behavior and the nonnetwork fraction as well as the molecular mobility of the network component.

Key Word : Pulsed NMR, Solid scho method, Hahn echo method, Higher order structure, Bound rubber, Network component, Non-network component, Filler, Fatigue

\section{1.は じ め に}

新しいゴム製品を設計するとき，又はトラブルを短期間 で解決しなければならないときに一番困るのは，ゴム製品 の機能や動的寿命を予測出来ない場合が多いことである. ほとんどを計算で設計することも可能な金属製品とは対照 的に，高次構造が容易には特定出来ないゴム製品の設計は 経験に頼るところが多い，その結果，機械要素の設計図面 の中でのゴム部品の要求特性は硬度だけという場合が多く なる。この現状は，ゴム部品が用いられる機械要素への要 求特性が益々厳しくなっている昨今では, とても対応可能 とは言い難く，ゴム部品の設計段階で出来るだけ定量的な

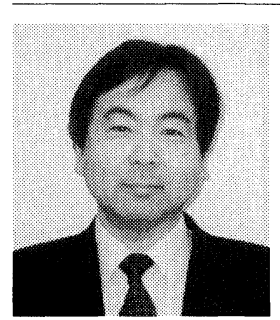

${ }^{* 1}$ 日信工業(株開発センター長野開発技術 ( ⿳ 389-0514 長野県小県郡東部町大字加沢 801 )。昭和 52 年東北大学工学部金属工業科 卒業. 昭和 61 年神戸大学大学院自然科学研 究科修了. 昭和 $61 \sim$ 平成 13 , 三ッ星ベルト (株), 平成 14 日信工業(侏). 専門は, ゴムの 構造と物性. 編集委員.
高次構造評価を取り入れることが必要と思われる.

\section{2. 構造の評価・・・パルス法 NMRで何が分かるか}

\section{1 各種評価法}

ゴムの高次構造特定が困難な理由は，ゴム分子が液体の ように活発に運動していること ${ }^{1)}$, 架橋により形成される 三次元網目構造の不均質性 ${ }^{2-6)}$, およびカーボンブラック (CB) などの補強剤による不均質性などのゴムの高次構造 の複雑さによると考えられる ${ }^{5), 7), 8)}$. 例えば，複雑な複合 材料であるゴム製品では架橋密度の決定すら難しい場合が 多く9), CBやシリカのような補強剤によるゴムの高次構 造変化は現在でも議論の的となっている10),11)。また，短

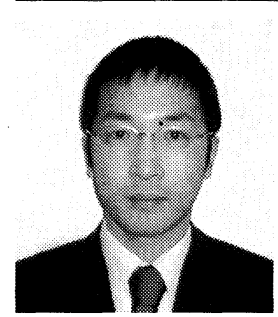

*2岡山県工業技術センター材料技術部 ( $\bar{T} 701-$ 1296 岡山市芳賀 5301) 研究員. 平成 5 年, 神戸大学大学院工学研究科工業化学専攻修 了. 同年, 岡山県工業技術センター入所. 現在に至る，専門は，エラストマーの構造 と物性. 
繊維による補強では，短繊維/ゴム界面には特殊なゴムの 層が形成されることが報告されている ${ }^{12)-14)}$.これらのゴ ム分子の高次構造を調べる手法として, 動的粘弾性 (DMA) が有効であることはよく知られ11),14)-17)，また， $\mathrm{CB}$ の形態観察には透過型電子顕微鏡 ${ }^{18)}$, 走査型プローブ 顕微鏡 $(\mathrm{SPM})^{19)}$ が用いられている. 一方, ゴム分子のよ うに活発に分子運動する物質は, その分子運動性を知るこ とが重要となる20),21)。DMA 測定によって得られる損失 係数 $\tan \delta$ は分子運動性の尺度となるが定量性に欠ける難 点がある. 分子運動性の尺度という点では, パルス法 NMR 測定によって求められるスピンースピン緩和時間 $\left(\mathrm{T}_{2}\right)$ が複数の不均質成分を定量的に分離することが可能 なことから ${ }^{21)}, 30$ 年ほど前から精力的に研究が行われて きた ${ }^{20)}$. 以下に，日本ゴム協会誌に揭載された最近 5 年 間程度の新しい研究を中心に振り返ることによって，パル ス法NMRによるゴム研究の将来を占ってみたい.

\section{2 パルス法NMRの測定原理}

NMR 緩和の理論は大変難しいので, 知っておく必要が ある事柄のみ概説したい. NMRで見られる緩和現象は, 核スピン系相互でのエネルギー交換，もしくは核スピン系 とそれ以外の自由度(格子)との間のエネルギー交換による ものであり，主に核スピン間の双極子-双極子相互作用に 基づく．この相互作用は分子運動による変調を受け，それ に伴い核磁気緩和現象が観測される ${ }^{22)}$.つまり，NMRで は分子運動からの変調を見ることになるため, 応力という 刺激を加えて応答を見る力学緩和 (DMA) とは原理的に異 なる，そのためパルス法NMRでは，他の手法では得られ ない分子運動に関する詳しい情報を与えることになる．ス ピンースピン緩和時間 $\mathrm{T}_{2}$ が分子運動性の尺度となる理由の

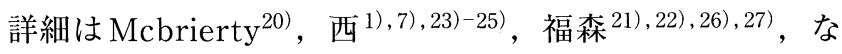
どの論文，解説を参考にして頂きたいが，分子運動の相関 時間 $\tau \mathrm{c}$ と $\mathrm{T}_{2}$ の関係から理解される。 $\tau \mathrm{c}$ は，ある運動状 態にある分子が分子衝突を起こす平均的な時間を表し, $\mathrm{T}_{2}$ の值は $\tau \mathrm{c}$ の増加と逆比例して短くなることが知られて いる.これは分子運動性が低下するにつれて $T_{2}$ が短くな ることを示しており，また， $\mathrm{T}_{2}$ は分子運動の高周波およ び低周波成分の両者の影響を受けることも特徵として知ら れている．観測核はプロトンである場合がほとんどで，カ 一ボンブラック, シリカなどの充てん剂にほとんどプロト ンがないことから，充てん剤からの信号を心配する必要が ないのも利点である．以上のように，パルス法NMRは高 分解能 NMRのように化学種ごとの情報は得ることができ ないが, 分子の運動性, 高次構造に対応した緩和現象が観 測される， $\mathrm{T}_{2}$ の測定は，ガラス管に詰めた試料を磁場の 中に置き, 高周波パルス磁場を加えた後の巨視的磁化の緩 和挙動を測定する.パルスのかけ方は多種類開発されてお り，目的に応じて使い分ける． $\mathrm{T}_{2}$ の短い固体については
ソリッドエコー法， $\mathrm{T}_{2}$ の非常に長い液体は CPMG (CarrPurcell-Meiboom-Gill) 法が測定法として適し，ゴム分子の ような中間的な分子運動性を有するものにはハーンエコー 法が適すると考えられる。

\section{3 応用例}

Fig.1に著者らが $150{ }^{\circ} \mathrm{C}$ で測定したパーオキサイド $2 \mathrm{phr}$ で架橋したEPDM 純ゴムのハーンエコー法による減衰曲 線を一例として示す．緩和現象は信号の減衰となって示さ れている。この信号強度は指数関数的に減少し, EPDM が均一な構造であれば図中で 1 本の直線になるが, 図から 明らかなように，指数型の早い減衰成分とゆっくり減衰す る同じく指数型の成分の 2 成分から成る不均質体であるこ とが分かる. 両成分は非線形最小二乗法を用いて $\mathrm{T}_{2 \mathrm{~s}}=$ $611 \mu \mathrm{sec}\left(\mathrm{fs}_{\mathrm{S}}=0.888\right)$ と $\mathrm{T}_{2 \mathrm{~L}}=3.59 \mathrm{msec}\left(\mathrm{f}_{\mathrm{L}}=0.112\right)$ の 2 成 分に分離され，ここで $\mathrm{fs}, \mathrm{f}_{\mathrm{L}}$ はそれぞれの成分分率である. Folland らは放射線架橋したポリイソプレンゴムの不均質 性を，化学網目や物理的絡み合いのような網目鎖に相当す るネットワーク成分と網目に関与しない非ネットワーク成 分の 2 成分に分離し，また，ネットワーク成分の緩和時間 $\mathrm{T}_{2}$ の逆数が架橋密度と強い相関のあることを示した ${ }^{3), 4)}$. Fig.1のパーオキサイド架橋したEPDM系でも同様に, $\mathrm{T}_{2 \mathrm{~s}}$ 成分はネットワーク成分, $\mathrm{T}_{2 \mathrm{~L}}$ 成分は非ネットワーク成分 に相当すると考えられる ${ }^{28)}$ ，架橋ゴムではネットワーク 成分に依存する物性評価が多いが，パルス法NMRでは非 ネットワーク成分の情報もかなり定量的に得られることに なるので，新たな観点でゴム製品の開発に取組むことが可 能となる，著者らの測定では, 繊維などの結晶, 非晶質の 固体などの $\mathrm{T}_{2}$ は数 $\mu \mathrm{sec}$ 数 $10 \mu \mathrm{sec}$ と非常に短く, 水, オイルなどの液体は $3 \mathrm{msec}$ 以上と長くなり，ゴムは種類 により多少は異なるが $100 〜 1000 \mu \mathrm{sec}$ の值が得られてい る. Fig.1で示した $\mathrm{T}_{2 \mathrm{~L}}$ は $3.59 \mathrm{msec}$ と非常に長いことから, 非ネットワーク成分の分子運動性は液体に相当し，この成 分は $11 \%$ 程度存在することになる.

ゴムの不均質性を明らかにする研究として, 藤本, 西ら ${ }^{1)}$ に代表されるカーボンブラック充てんゴムの不均質構造の

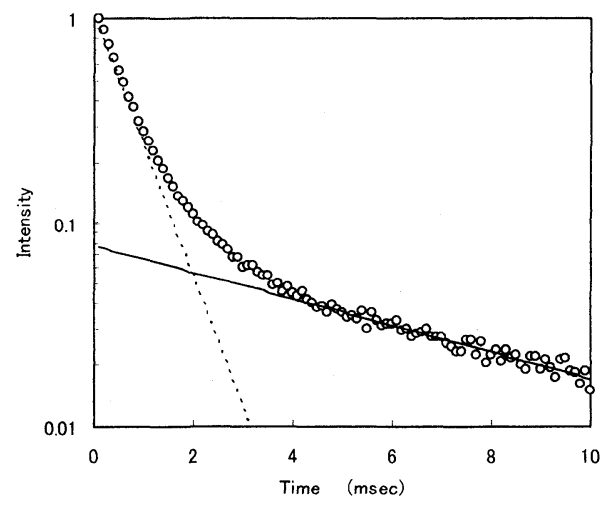

Fig.1 $\mathrm{T}_{2}$ signal for peroxiside-cured EPDM at $150^{\circ} \mathrm{C}$ by Hahn echo method. 
研究が有名である. $\mathrm{CB}$ 周辺から離れた $\mathrm{A}$ 相, 架橋ゴム分 子の凝集相の $\mathrm{B}$ 相, および $\mathrm{CB}$ 周辺に形成される稠密構造 のC相という高次構造のモデルが提案され，その後のバウ ンドラバーの構造解明を初めゴムの不均質構造の研究に大 きな影響を与えた ${ }^{29)-34)}$.ここで，バウンドラバーとは， 充てん剂を混練りした未架橋のゴムを溶剤抽出した際，充 てん剤と結合したまま抽出されずに残ったゴム分のこと で, 充てん剂による補強の要因の一つと考えられている. これ以外に, 大変形時の高次構造の変化 $\left.\left.\left.{ }^{26)}, 27\right), 35\right), 36\right)$, 熱 劣化の追跡 ${ }^{37)-39)}$, 膨潤時の変化 ${ }^{40), 41)}$, ブレンドの相構造 や界面の構造 23)，24，42，43）などもパルス法 NMRで追跡可 能である。

\section{3. 最近のバウンドラバーの研究}

\section{1 バウンドラバーの構造モデル}

$\mathrm{T}_{2}$ の短いバウンドラバーを検出するために主にソリッ ドエコー法が用いられている．藤本らはC 相の考え方をも とに，粒子濃度とゴムの物性の関係を総合的に研究した 44)。一方，混練り後のゴムを溶媒に浸せきし不溶のゲルを 乾燥して測定すると，より詳しい情報を得ることが出来る. $\mathrm{CB}$ と EPDMの混練りでは, ごく初期にバウンドラバーは 生成し, $\mathrm{T}_{2}$ の短い tight な $\mathrm{T}_{2 \mathrm{~S}}$ 成分と $\mathrm{T}_{2}$ の長い loose な $\mathrm{T}_{2 \mathrm{~L}}$ 成分の 2 種類に分離される ${ }^{34)}$. 西は四塩化炭素による膨潤 によって $\mathrm{T}_{2 \mathrm{~L}}$ は長くなるが $\mathrm{T}_{2 \mathrm{~S}}$ は変化しないことから, NR 分子が $\mathrm{CB}$ 表面に強く吸着していると推察した ${ }^{40)}$. 伊藤ら は ${ }^{32)}$, シリカ微粒子を BRのベンゼン溶液中で混合した後, 抽出したシリカバウンドラバーも tight と loose の 2 成分に 分離され，熱処理によって tight相が増加することを示し た。このような $\mathrm{CB}$ やリカなどの充てん剤表面のゴム分 子の稠密構造について, O'Brienが提案したモデルが有名 である ${ }^{45)}$ ，パルス法NMRで分離された tightな成分は, 充てん剂表面への物理吸着鎖, 化学結合鎖, 数ヶ所で吸着 された分子鎖，および折りたたみ鎖や一端固定鎖の充てん 剤表面部分であり，この拘束領域の厚さは数 $\mathrm{nm}$ 程度と見 積もられる。一方, looseな成分は充てん剂から離れた部 分で十分活発な分子運動を行っている部分に相当すると考 えられる7).

\section{2 バウンドラバー構造解明の発展}

バウンドラバーを様々な角度から研究してきた伊藤，八 柳らは，これらの 2 成分に加えて中間的運動性を示す $\mathrm{T}_{2 \mathrm{~m}}$ 相の存在を示し, 修正した構造モデルを提案した ${ }^{46)}$. 分 子量増加に伴う $T_{2 L}$ 成分の増加は $\mathrm{CB}$ に吸着しているゴム 分子鎖がループあるいはテイルを形成し，その長さが分子 量増大とともに長くなるためと考える。ここで，ループは 両端が $\mathrm{CB}$ 表面に固定され，また，テイルは片方が固定され ている末端鎖がある分子鎖のセグメントのことである ${ }^{8)}$. このような $\mathrm{T}_{2 \mathrm{~L}}$ 相の発達につれて $\mathrm{T}_{2 \mathrm{~L}}$ 相と $\mathrm{T}_{2 \mathrm{M}}$ 相の構造差
が明確になるとしている，この中間成分の存在はSBRで も Lüchowらが確認している ${ }^{31)}$. 更に, バウンドラバーの $\mathrm{T}_{2 \mathrm{~L}}$ 相中には $\mathrm{CB}$ に直接吸着していないゴム分子鎖が含ま れることを示している ${ }^{30)}$ ，八柳らが報告した眝蔵弾性率 とバウンドラバー成分量の関係の抜粋を Fig. $2-4$ に示した 10). Fig.2に示すように，分子運動が高度に拘束されたゴ ム成分の成分量の和 $\mathrm{f}_{\mathrm{M}+\mathrm{S}}$ は温度上昇により急激に減少す る.この $\mathrm{f}_{\mathrm{M}+\mathrm{S}}$ と貯蔵弾性率の $\mathrm{CB}$ による増加率 $\mathrm{E}_{\mathrm{f}}^{\prime} / \mathrm{E}_{0}^{\prime}$ の 関係はFig.3に示す通り，一定のCB充てん量においては よく相関している。これは $\mathrm{f}_{\mathrm{M}+\mathrm{S}}$ の温度変化が貯藏弾性率 の温度依存性に影響を与えていることを示している．更に 八柳らは一歩進んで, 䝪蔵弾性率の温度依存性がオクルー ドラバー構造の温度変化で説明できると考えた。オクルー ドラバーによる補強は古くから提唱されている概念で，才 クルードラバーは充てん剤ストラクチャー凝集体の内部空 隙空間に入り込んでいるゴムを示している ${ }^{47)}$. したがっ て，オクルードラバー中の $\mathrm{T}_{\mathrm{M}+\mathrm{S}}$ 相は CBアグリゲート構 造の内部に存在することから，その量はゴム中のオクルー ドラバーの成分分率に比例し， $\mathrm{f}_{\mathrm{M}+\mathrm{S}}$ とオクルードラバー の成分分率との積 $\left(\mathrm{f}_{\mathrm{M}+\mathrm{S}} \times \mathrm{G}_{\mathrm{occ}}\right)$ をその尺度とし, Fig.4の 横軸としている．図から分かるように，各充てん量におい

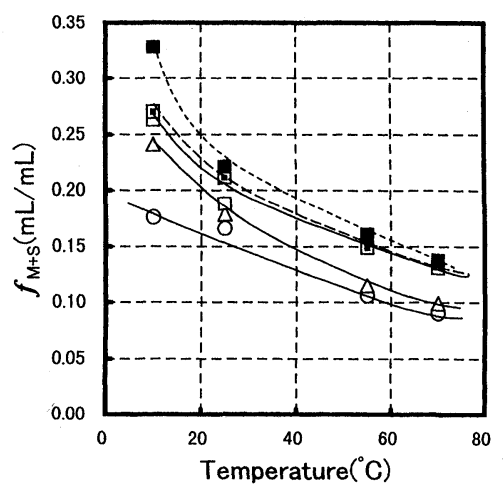

Fig.2 Temperature dependence of $f_{M+S}$ for black filled SBR systems (open:HAF1 grade carbon black, dotted:HAF2 grade carbon black, filled:SAF grade carbonblack, circle:carbon black/rubber $=30 / 100$, triangle:carbon black/rubber $=60 / 100$, square: carbon black/rubber $=90 / 100)^{10)}$

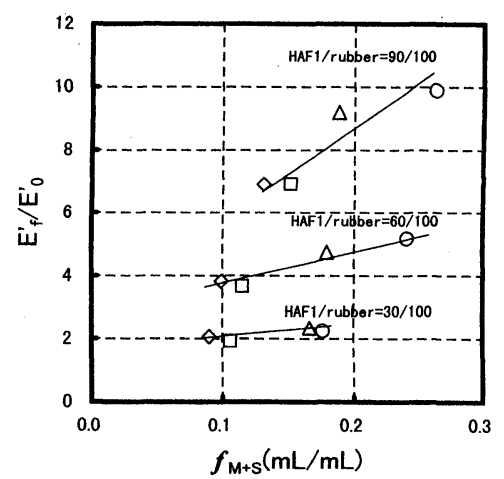

Fig.3 Relationship between $\mathrm{f}_{\mathrm{M}+\mathrm{S}}$ and $\mathrm{E}_{\mathrm{f}}^{\prime} / \mathrm{E}_{0}^{\prime}$ at DSA of $2 \%$ for black filled SBR systems (circle: $10{ }^{\circ} \mathrm{C}$, triangle: $25{ }^{\circ} \mathrm{C}$, square: $55{ }^{\circ} \mathrm{C}$, rhomb:70 $\left.{ }^{\circ}\right)^{10)}$ 


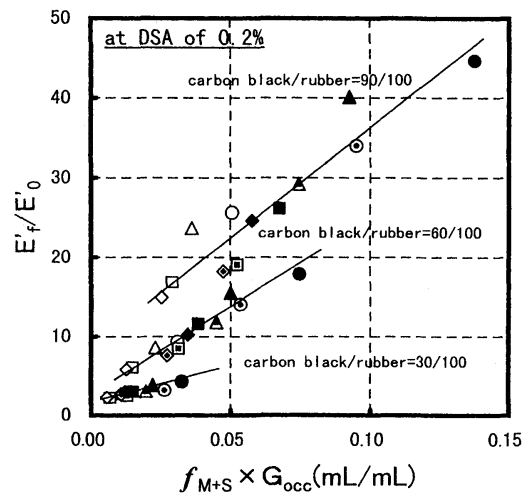

Fig.4 Relation between $\mathrm{f}_{\mathrm{M}+\mathrm{S}} \times \mathrm{G}_{\mathrm{occ}}$ and $\mathrm{E}_{\mathrm{f}}^{\prime} / \mathrm{E}_{0}^{\prime}$ at DSA of $0.2 \%$ for black filled SBR systems (open:HAF1 grade carbon black, dotted:HAF2 grade carbon black, filled:SAF grade carbonblack, circle: $10^{\circ} \mathrm{C}$, triangle: $25^{\circ} \mathrm{C}$, square: $55^{\circ} \mathrm{C}$, rhomb: $70^{\circ} \mathrm{C}$ ) $\left.{ }^{10}\right)$

て, $\mathrm{CB}$ の種類および温度によらず $\mathrm{E}_{\mathrm{f}}^{\prime} / \mathrm{E}_{0}^{\prime}$ は $\mathrm{f}_{\mathrm{M}+\mathrm{S}} \times \mathrm{G}_{\mathrm{occ}}$ に対して同一直線上に位置し，これはオクルードラバー中 の $\mathrm{T}_{\mathrm{M}+\mathrm{S}}$ 相の量が温度上昇により減少した結果，貯蔵弾性 率の低下をもたらしたことを示している。

深堀は最近の著書 ${ }^{48)}$ で，バウンドラバー相は未架橋状 態に近いとの仮説の上でCBによる補強とペイン効果 ${ }^{49)}$ などの様々な現象を説明している。これらの指摘は，バウ ンドラバー相は樹脂のような挙動を示すことを示唆してお り，藤本らが示したC相量の増加につれて系の弾性はエン トロピー弾性からエントロピー弾性とエネルギー弾性の混 合した複合系に転移するとの実験結果 ${ }^{50)}$ との関連を想起 させる，バウンドラバー相の樹脂的挙動は，深堀の指摘の ように数々の問題を含んでおり，著者らの注目する高温で 使用されるゴム製品の特性にも大きな影響を与えると推定 され ${ }^{51)}$ ，今後更に詳細な究明が必要である.

\section{4. 架橋構造と動的疲労の研究}

\section{1 パルス法 NMRによる架橋構造の研究}

初めに, 継続的にパルス法NMRを用いて研究している
グループの，文献上現れた架橋構造に対する考え方をまと めTab.1に示した。藤本は，C相を中心に不均質モデルを 提案したが1)，B相についての考察は多くない。その後， 西は溶剂による構造変化を調べる実験では，バウンドラバ 一の tight相とゴム相の 2 成分に分離した。ここでは，ゴ ム相は 1 成分となっている．伊藤，八柳らはソリッドエコ 一法で得られた減衰曲線を 3 成分に分離し， $\mathrm{T}_{2}$ の短い 2 成分， $\mathrm{T}_{2 \mathrm{~S}}$ と $\mathrm{T}_{2 \mathrm{M}}$ を $\mathrm{CB}$ 近傍で運動が強固に拘束されたゴ ム相と考えている ${ }^{10)}$ 。したがって，マトリックスである ゴム相は 1 成分ということになる。また，福森らは，NBR の $\mathrm{T}_{2}$ の短い成分を架橋点近傍のネットワーク鎖, $\mathrm{T}_{2}$ の長 い成分を架橋点から離れたネットワーク鎖とした ${ }^{26)}$ 。こ のように，ゴム相は 1 成分もしくは 2 成分と見解の相違が 見られる．1成分の場合，パルス法NMRで見る限りゴム 相は均質ということになる．2成分と考える場合は，架橋 点近傍と架橋点から離れたゴム分子の分子運動性は異な り，構造的にも異質と捉えることができる．事項で述べる が，著者らはEPDMについて，ハーンエコー法で2成分， ソリッドエコー法で 3 成分に分離した不均質構造を提案し ている ${ }^{9,28), 51)}$ 。これらの結果の相違は，ゴムの種類，配 合, 加工法, 架橋条件, およびNMR測定条件，解析条件 などによると考えられる。

\section{2 新しい架橋構造考察法の提案}

Tab.1に示すように，パーオキサイド架橋EPDMはソリ ッドエコー法では 3 成分に分離されたが，数十 $\mu$ secより 短い $\mathrm{T}_{2}$ の成分は検出されず，CRでも同様であった ${ }^{51), 52)}$. このようにバウンドラバー相が検出されないのはLüchow らのSBRの結果 ${ }^{31)}$ と同様に，コンパウンドではバウンド ラバーの成分量が少ないため検出されなかったためと考え られる. Tab.1に示した 3 成分について，M1成分は最も分 子運動性が低く温度による成分分率の変化がほとんどない ことから架橋点近傍の分子凝集相 (架橋相)，M2成分はゴ ム相の大部分を占め, 架橋の進行に伴って増加することか

Tab.1 Heterogeneity of cured rubbers

\begin{tabular}{|c|c|c|c|}
\hline Researchers & Method & Components & Heterogeneity \\
\hline \multirow{3}{*}{ K.Fujimoto et al for $\mathrm{NR}^{1}$, } & \multirow{3}{*}{ Solid echo at $30^{\circ} \mathrm{C}$} & $\mathrm{T}_{2 \mathrm{~S}}(10 \mu \mathrm{s})$ & C-phase \\
\hline & & $\mathrm{T}_{2 \mathrm{M}}(60 \mu \mathrm{s})$ & B-phase \\
\hline & & $\mathrm{T}_{2 \mathrm{~L}}(600 \mu \mathrm{s})$ & A-phase \\
\hline \multirow{2}{*}{ T.Nishi et al for $\mathrm{NR}^{77,40)}$} & \multirow{2}{*}{$90^{\circ}$ pulse at r.t. } & $\mathrm{T}_{2 \mathrm{~S}}(20 \mu \mathrm{s})$ & Immobilized layer around $\mathrm{CB}$ \\
\hline & & $\mathrm{T}_{2 \mathrm{~L}}(200 \mu \mathrm{s})$ & Rubber phase \\
\hline \multirow[t]{2}{*}{ M.Ito Et al For SBR ${ }^{10)}$} & \multirow[t]{2}{*}{ Solid echo at $30^{\circ} \mathrm{C}$} & $\begin{array}{l}\mathrm{T}_{2 \mathrm{~S}}(20 \mu \mathrm{s}) \\
\mathrm{T}_{2 \mathrm{M}}(100 \mu \mathrm{s})\end{array}$ & Tight layer around $\mathrm{CB}$ \\
\hline & & $\mathrm{T}_{2 \mathrm{~L}}(800 \mu \mathrm{s})$ & Rubber molecules \\
\hline \multirow{2}{*}{ K.Fukumori et al for NBR ${ }^{26)}$} & \multirow{2}{*}{ Solid echo at $30^{\circ} \mathrm{C}$} & $\mathrm{T}_{2 \mathrm{~S}}(50 \mu \mathrm{s})$ & Network chains in the vicinity of the crosslinks \\
\hline & & $\mathrm{T}_{2 \mathrm{~L}}(150 \mu \mathrm{s})$ & Network chains farther from the crosslinks \\
\hline \multirow{5}{*}{ T.Noguchi et al for EPDM } & \multirow{3}{*}{ Solid echo at $30^{\circ} \mathrm{C}^{9)}$} & $\mathrm{T}_{2 \mathrm{M} 1}(250 \mu \mathrm{s})$ & Molecules surrounding crosslinking points \\
\hline & & $\mathrm{T}_{2 \mathrm{M} 2}(500 \mu \mathrm{s})$ & Molecules between crosslinking points \\
\hline & & $\mathrm{T}_{2 \mathrm{M} 3}(2000 \mu \mathrm{s})$ & Non-network molecules \\
\hline & \multirow{2}{*}{ Hahn echo at $30^{\circ} \mathrm{C}^{28)}$} & $\mathrm{T}_{2 \mathrm{n}}(500 \mu \mathrm{s})$ & Network molecules \\
\hline & & $\mathrm{T}_{2 \mathrm{nn}}(2400 \mu \mathrm{s})$ & Non-network molecules \\
\hline
\end{tabular}


ら架橋点間の分子運動が活発な分子相(架橋点間分子相)に 対応すると考えられる．M3成分は $2 \mathrm{msec}$ を超える液体に 近い分子運動性を有し, 架橋の進行に伴って減少すること から網目構造に関与しない成分であり，末端鎖 (ダングリ

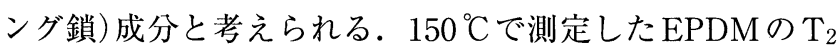
の見かけの架橋密度 $(\nu \mathrm{e})$ による変化を Fig.5に示した.

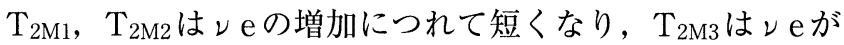
増加してもあまり変化せず，架橋の進行に伴う各成分の挙 動がよく分かる．充てん剤の影響を見ると，シリカおよび 炭酸カルシウムの $60 \mathrm{phr}$ 配合系は, 純ゴム配合とほぼ同じ 線上にプロットされるが，CB配合系は同じ架橋密度で見 ると $\mathrm{T}_{2}$ は長い。これら充てん剤の影響を見ると，充てん

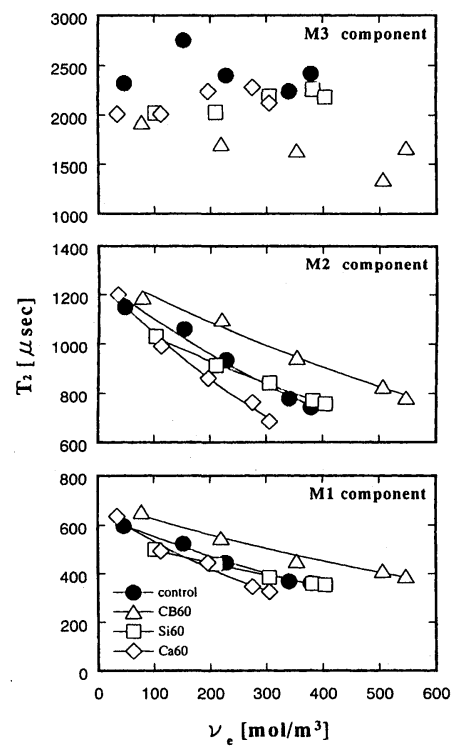

Fig.5 Relationships between $\tan \delta$ values at $150^{\circ} \mathrm{C}$ and fraction of each component at $150^{\circ} \mathrm{C}$ for some kinds of filler loaded EPDMs containing some kinds of filler of $60 \mathrm{phr}^{9)}$

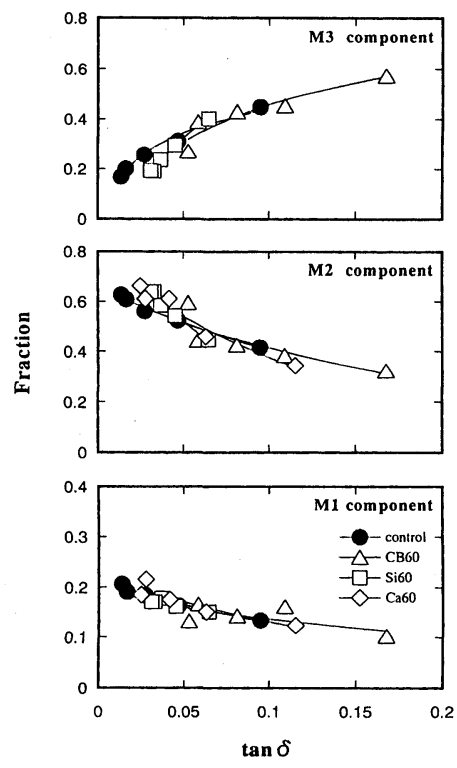

Fig.6 Relationships between crosslinking $\operatorname{density}(\nu$ e $)$ and spin-spin relaxation time $\left(\mathrm{T}_{2}\right)$ of each component at $150{ }^{\circ} \mathrm{C}$ for EPDMs containing some kinds of filler of $60 \mathrm{phr} .{ }^{9)}$
剤それ自身はEPDMの架橋構造にあまり大きな影響を与 えないことを示している，ただし，CBはゴム分子を吸着 して補強するとの考え方から見ると矛盾するように見える が，深堀の提案との関連も含めて今後の検討課題である. Fig. 6 に $150{ }^{\circ} \mathrm{C} て ゙$ 測定した $\tan \delta$ 值と成分分率の関係を示 す。ここで注目されるのは図から明らかなように，純ゴム 系と 3 種類の充てん剂配合系がほとんど同一の線上に表さ れるということである.今後, 充てん剤の種類やゴムの種 類など，様々な検討を加える必要があるが，高温での tan $\delta$-成分分率の関係は，充てん剂に影響を受けない架橋 構造の考察法として基礎的にも工業的にも有用と考えられ る.

\section{3 動的疲労とパルス法NMRパラメータ}

加硫ゴムの疲労過程の構造変化を追及した藤本らは A 相はエントロピー増大方向, 準ガラス状態のC相はエント ロピー減少方向の熱力学的安定状態に進み, 系はますます 不均質な構造となるとしている ${ }^{53)}$. 伊藤らはNRにおいて, 低温 $\left(100^{\circ} \mathrm{C}\right.$ 以下)の力学的刺激ではゴム相は稠密化の方向 に進み，高温 $\left(160^{\circ} \mathrm{C}\right.$ 付近 $)$ の力学的刺激ではゴム分子鎖の 運動性増加による軟化方向へ進むことを報告している ${ }^{54)}$. また，長谷川らは疲労の初期に特徵的な変化があることを 報告している55)

このような疲労過程の構造変化を踏まえて，著者らは動 的疲労挙動を予測するため未疲労試料の分子運動性および 構造と疲労挙動の関係を調べている.Tab.2 にCRの配合 系と $\mathrm{M} 3$ 成分が観測される温度を示す ${ }^{51)}$. CR 純ゴム配合 系は $90^{\circ} \mathrm{C}$ 以上で初めて $\mathrm{M} 3$ 成分が検出され，これに $\mathrm{CB}$ 配合すると M3成分が検出される温度が高温側に移動し, これはCBが末端鎖の運動を抑制したことを示している. また，粒径の大きいSRFブラックを用いたときは測定し た最高温度の $150{ }^{\circ} \mathrm{C} て ゙ さ え \mathrm{M} 3$ 成分は検出されなかった。 このように見かけの架橋密度や硬度がほぼ同等であるにも

Tab.2 Compound recipe and properties of four kinds of crosslinked CR. ${ }^{51)}$

\begin{tabular}{lcccc}
\hline & Unfilled CR & Sample A & Sample B & Sample C \\
\hline $\mathrm{CR}$ & 100 & 100 & 100 & 100 \\
$\mathrm{MgO}$ & 4 & 4 & 4 & 4 \\
$\mathrm{ZnO}$ & 5 & 5 & 5 & 5 \\
Stearic acid & 1 & 1 & 1 & 1 \\
Ethylene thiourea & 0.25 & 0.25 & 0.25 & 0.25 \\
HAF black & - & 40 & - & - \\
MAF black & - & - & 40 & - \\
SRF-LM black & - & - & - & 60 \\
\hline Hardness & 49 & 77 & 78 & 76 \\
M100 (MPa) & 1.2 & 6.6 & 7.1 & 5.3 \\
TB (MPa) & 28.4 & 26.0 & 23.5 & 21.8 \\
EB (\%) & 825 & 312 & 315 & 284 \\
\hline Crosslinking density $\left(\mathrm{mol} / \mathrm{m}^{3}\right)$ & 146 & 324 & 338 & 330 \\
\hline TL ( $\left.{ }^{\circ} \mathrm{C}\right)$ & 90 & 110 & 110 & - \\
\hline
\end{tabular}

$\mathrm{TL}$ : temperature at which $\mathrm{T}_{2}$ of $\mathrm{M} 3$ component becomes longer than 2 msec. 
かかわらず， $\mathrm{CB}$ の種類よって未端鎖の検出される温度に 違いが見られる. Fig.7にTab.2のサンプルBとCの動的疲 労時の繰返し最大応力の保持率を示す. M3 成分が認めら れない条件では応力の保持率は初期に低下し500サイクル 以後ほぼ一定となるが, $\mathrm{M} 3$ 成分が検出される $130{ }^{\circ} \mathrm{C}$ の ンプルBでは, 繰返しサイクルの増大につれて応力保持率 は徐々に低下し止まらない.この応力の単調な低下は疲労 破壊が近いことを確認しているので，末端鎖の運動が開放 される条件では動的疲労が著しくなることが分かる.逆に， $\mathrm{M} 3$ 成分が $150{ }^{\circ} \mathrm{C}$ の高温でも検出されなかった SRF ブラッ クは耐疲労性を向上させているが，これは一般に知られる $\mathrm{CB}$ による補強効果とは逆の傾向である. 現在推定できる ことは, 粒径の小さいHAFブラックなどに比べて SRF ブ ラックがゴム中での分散が良いことや，バウンドラバーの 高温での影響 48) などが考えられるが, 今後の検討課題で ある。また，粒径約 $5 \mathrm{~nm}$ の $\mathrm{Au}$ の超微粒子を $0.6 \mathrm{phr}$ 配合し た $\mathrm{CR}$ 複合体では $150{ }^{\circ} \mathrm{C}$ 高温でも $\mathrm{M} 3$ 成分は検出されず, 高温での耐疲労性の改善が認められている ${ }^{52)}$ 。これらの 結果は，末端鎖の分子運動が動的疲労挙動に強い影響を及 ぼすことを示し, 末端鎖の分子運動性や構造を制御すれば 動的疲労挙動を制御しうる可能性を示唆している.

$\mathrm{T}_{2}$ の長い成分を精度良く観測するために用いられるハ

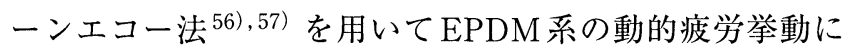
ついて説明する ${ }^{28)}$. 不均質構造はTab.1に示すように, 2 成分に分離される.ソリッドエコー法で得られた $\mathrm{T}_{2 \mathrm{M} 1}$ 成 分と $\mathrm{T}_{2 \mathrm{M} 2}$ 成分が，ハーンエコー法の $\mathrm{T}_{2 \mathrm{n}}$ 成分に相当し,

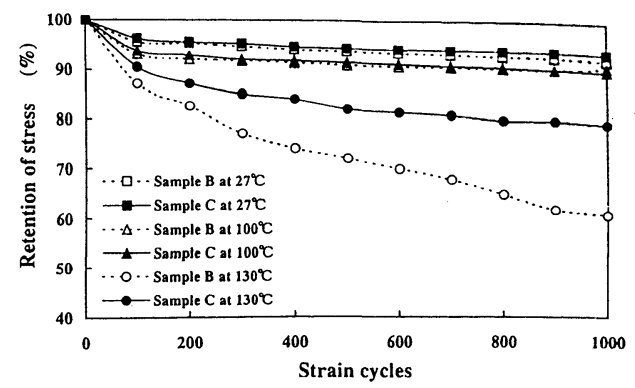

Fig.7 Fatigue behaviors in cyclic elongation test at $0 \%-50 \%$ repetitive strain for sample B and C. ${ }^{51}$

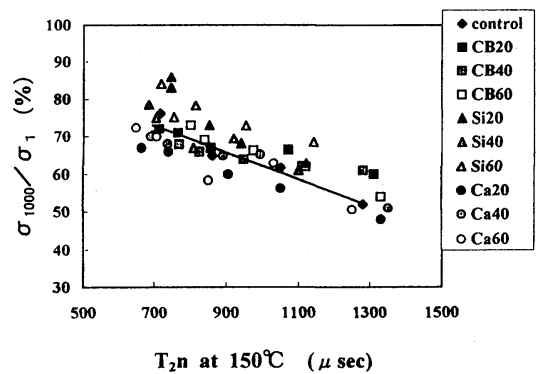

Fig.8 Relationships between the retention of $\operatorname{stress}\left(\sigma_{1000} / \sigma_{1}\right)$ under fatigue at $150{ }^{\circ} \mathrm{C}$ and $\mathrm{T}_{2 \mathrm{n}}$ at $150^{\circ} \mathrm{C}$ for EPDMs. The solid line was obtained by approximating the values for control specimens by the method of least squares. ${ }^{28)}$

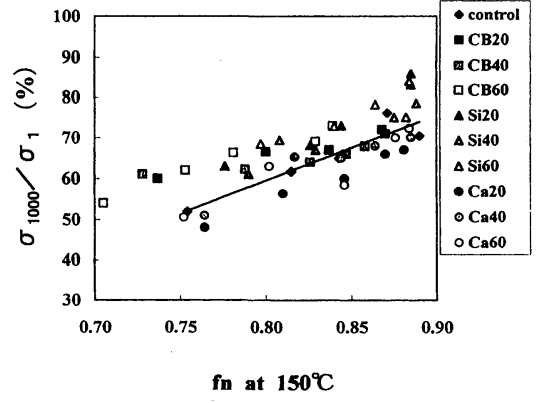

Fig.9 Relationships between the retention of stress $\left(\sigma_{1000} / \sigma_{1}\right)$ under fatigue at $150{ }^{\circ} \mathrm{C}$ and $f_{n}$ at $150{ }^{\circ} \mathrm{C}$ for EPDMs. The solid line was obtained by approximating the values for control specimens by the method of least squares. ${ }^{28)}$

$\mathrm{T}_{2 \mathrm{M} 3}$ 成分が $\mathrm{T}_{2 \mathrm{nn}}$ 成分に相当すると考えられる．先に示し たように， $\mathrm{T}_{2 \mathrm{n}}$ 成分はネットワークに関与する成分で，化 学網目と物理的絡み合いなどからなる成分, $\mathrm{T}_{2 \mathrm{nn}}$ 成分は非 ネットワーク成分で末端鎖成分と考えられる. Fig.5に示 したように，EPDMは CR と異なり $30^{\circ} \mathrm{C}$ の低温でも $\mathrm{M} 3$ 成 分が検出されるため, CRのように $\mathrm{M} 3$ 成分すなわち $\mathrm{T}_{2 \mathrm{nn}}$ 成分の有無で明確に条件を設定することができない. Fig.8，9に3種の充てん剂を配合したEPDMに $150^{\circ} \mathrm{Cにて}$ 10\%の繰返し変形を与えた際の 1000 回繰返し時の応力保 持率と NMRパラメータの関係を示す. Fig.8の $\mathrm{T}_{2 \mathrm{n}}$ では, シリカ配合系が他の配合系より応力保持率は高めである が，全体的に $\mathrm{T}_{2 \mathrm{n}}$ が長くなるにつれて応力保持率は単調に 低下した。一方，Fig.9から fnが大きいほど応力保持率が 大きくなることが分かるが, カーボン配合系とシリカ配合 系はほぼ同じ直線上を増大し，純ゴム配合と炭酸カルシウ ム配合より応力保持率が大きい。このように，ネットワー ク成分の分子運動性が低く, 末端鎖の成分量が少ないほど 疲労による損傷が小さくなる傾向が認められる. 架橋密度 が高すぎると脆くなるため最適性があると思われるが，こ こでは現れていない。また，横軸に取るパラメー夕によっ て，充てん剤による影響は異なるものとなり，当初から予 想されたことではあるが，このような単純なパラメータだ けでは複雑な疲労挙動を説明するのは限界があると思われ る. 今後, パラメータの詳細な検討は重要な課題である. このように動的寿命を予測する試みは始まったばかりであ るが，パルス法NMRによっていくつかの手がかりが国め たことは事実である。

\section{5. 近年の学会発表でのパルス法 NMRによる研究}

最近の日本ゴム協会年次大会およびエラストマー討論会 で議論されている新しい試みについて概説する。

仲濱らはペイン効果 ${ }^{49)}$ を逆に応用して新しい混練指標 を提案するにあたって，混練によるゴムやゴム/CB界面の 構造変化をパルス法 NMRによって調べている ${ }^{58)}$. 従来の バウンドラバーの研究に加えて, カーボンブラックの凝集 
構造にも新しい知見を与えるものとして注目される。山田 らはセグメンテッドポリウレタンを 4 成分に分離し，構造 と物性の相関付けを検討している ${ }^{59)}$ 。ポリウレタンと架 橋ゴムの，それぞれの構造と物性の関係の知見が相互に活 用されることが期待される．佐藤らは $\mathrm{EPDM} の{ }^{13} \mathrm{C}$ 固体高 分解能NMRを用いた緩和現象の追跡を行っている ${ }^{60)}$. 固 体高分解能 NMR を用いるゴムの緩和現象の研究は, 化学 種を特定可能な点において非常に興味深く, 今後の進展が 期待される。また，架橋密度決定が困難な発泡ゴムについ て, 伊藤らは $\mathrm{T}_{2}$ により架橋密度を決定できることを示し ている ${ }^{61)}$.

\section{6.お わりに}

ここで紹介した研究以外にも多くの研究者や技術者がパ ルス法NMRを用いて，色々な目的に活用していると思わ れる. 更に，ゴム技術者が日常頼りにするような最重要の 道具の一つとして確立するために, 任意性のある測定条件, 解析法の中から, 確実な部分を標準化すること, また, NMR 測定で得られるパラメータと, 特に，ゴム製品の特 性の相関を明らかにすることが重要と思われる。このため に，ユーザとメーカの協力関係は元より，大学や公的研究 機関など中立の立場の研究者の仲介と協力が不可欠と思わ れる，最後に，今回の解説の内容が主に日本国内に限った こと, また，著者らの調査不足と理解不足を合わせてお詫 びしたい。

\section{参 考 文 献}

1 ) Fujimoto,K., Nishi,T. : Nippon Gomu Kyokaisi, 43, 465(1970)

2) Ono,K. : Nippon Gomu Kyokaisi, 64, 176 (1991)

3 ) Folland, R., Charlesby, A.: Polymer, 20, 207 (1979)

4 ) Folland, R., Charlesby, A.: Polymer, 20, 211 (1979)

5 ) Nishi,T. : Nippon Gomu Kyokaisi, 75, 48(2002)

6 ) Sibayama,M. : Nippon Gomu Kyokaisi, 75, 62 (2002)

7 ) Nishi,T. : Hyomen, 20, 316(1982)

8 ) Nishi,T. : Nippon Gomu Kyokaisi, 58, 232 (1985)

9 ) Iwabuki,H., Nagata,K., Noguchi,T., Yamada,E. : Nippon Gomu Kyokaisi, 75, 409(2002)

10) Yatuyanagi,F., Ito,M., Kaidou, H. : Nippon Gomu Kyokaisi, $\mathbf{7 4}$, $456(2001)$

11) Kodama,S. : Nippon Gomu Kyokaisi, 74, 218 (2001)

12) Ashida,M., Noguchi,T., Mashimo,S. : Nippon Gomu Kyokaisi, 61, 794 (1988)

13) Ashida,M., Noguchi,T., Mashimo,S.: J.Appl.Polym.Sci., 30, 1011 (1985)

14) Noguchi,T. : Nippon Gomu Kyokaisi, 74, $223(2001)$

15) Andrady, A.L.: Polym.Bulletin, 28, 103(1992)

16) Isono,Y. : Nippon Gomu Kyokaisi, 74, 212 (2001)

17) Muraoka,K. : Nippon Gomu Kyokaisi, 74, 242(2001)

18) Maebara,A., Akiyama,S. : Nippon Gomu Kyokaisi, 71, 90 (1998)

19) Shigeno,M. : Nippon Gomu Kyokaisi, 71, 103 (1998)

20) Mcbrierty.V.J., Douglass, D. C.: J. Polym.Sci.:Macromol.Rev.: 16 , 295(1981)
21) Fukumori,K. : Materials Life, 3, 40(1991)

22) Fukumori, K.: Toyota Tyииои Kenkyuиsyo R\&D Rev., 21, 23(1986)

23) Tanaka,H., Nishi,T.: J. Chem. Phys., 82, 4326 (1985)

24) Tanaka,H., Nishi,T. : Phys. Rev. B, 33, 32(1986)

25) Nishi,T.: Rubber Chem. Technol., 51, 1075 (1978)

26) Fukumori,K., Sato,N., Kurauchi,N. : Nippon Gomu Kyokaisi, 61, 561 (1988)

27) Fukumori,K., Sato,N., Kurauchi,N. : Nippon Gomu Kyokaisi, 65, 191 (1992)

28) Noguchi,T., Iwabuki,H., Nagata,K., Yamada,E. : Nippon Gomu Kyokaisi, 75, 469(2002)

29) Kaufman,S., Slichter,W.P., Davis,D.D.: J. Polym. Sci. : Part A-2, 9, $829(1971)$

30) Yatuyanagi,F., Kaidou,H., Kida,N., Ito,M. : Nippon Gomu Kyokaisi, 70, 274(1997)

31) Lüchow, E., Gronski,W.: Rubber Chem.Technol., 70, 747 (1997)

32) Ito,M., Nakamura,T., Tanaka,K.: J.Appl.Polym. Sci., 30, 3493(1985)

33) Serizawa,H., Ito,M., Kanamoto,T., Tanaka,K., Nomura,A.: Polymer J.: 14, $149(1982)$

34) Furuta,M., Hikasa,T., Kato,E.: J. Appl. Polym. Sci. : 31, 2325(1986)

35) Nishi,T., Chikaraishi,T.: J. Macromol. Sci., B19(3), 445(1981)

36) Oikawa,H., Murakami,K.: Polymer, 23, 1737 (1982)

37) Serizawa,H., Nakamura,T., Ito,M., Tanaka,K., Nomura,A.: Polymer J.: 15, 201 (1983)

38) Ono,S., Ito,M., Tanaka,K., Udagawa,Y. : Nippon Gomu Kyokaisi, 60, $330(1987)$

39) Fukumori,K., Sato,N., Kurauchi,N. : Materials Life, 2, 59(1990)

40) Nishi,T.: J. Polym. Sci., Polym. Phys. Ed., 12, 685(1974)

41) Fukumori,K., Kuraushi,T., Kamigaito, O.: Polymer, 31, 713(1990)

42) Watanabe,K. : Tyota Gousei Gihou, 41, 44(1999)

43) Toyota,A., Kodama,K., Nishimura,Y., Shimakage, M., Takeuchi. T., Hattori, I. : Nippon Gomu Kyokaisi, 75, 530 (2002)

44) Fujimoto,K. : Nippon Gomu Kyokaisi, 67, 676 (1994)

45) O’Brien,J., Cashell,F., Wardell,G.E., McBrierty.V.J.: Macromolecules, 9, 653(1976)

46) Yatuyanagi,F., Kaidou,H., Ito,M. : Nippon Gomu Kyokaisi, 67, 707 (1994)

47) Kraus,G.: J. Polym. Sci., Part B 8, 601(1970)

48) Fukahori,Y.: Sekkei notameno Koubunshi no Rikigaku, Gihoudou Syuppan, (2000), p.344

49) Payne,A.R.: J. Appl. Polym. Sci.: 9, 2273(1965)

50) Fujimoto,K., Takahara, H., Mihune, N. : Nippon Gomu Kyokaisi, 62, 98(1989)

51) Noguchi,T., Utsumi,T. : Nippon Gomu Kyokaisi, 74, 116(2001)

52) Iwabuki,H., Noguchi,T. : Nippon Gomu Kyokaisi, 74, 277 (2001)

53) Fujimoto,K. : Nippon Gomu Kyokaisi, 49, 869 (1976)

54) Ito,M., Tanaka,K., Utagawa,Y. : Nippon Gomu Kyokaisi, 59, 39 (1986)

55) Hasegawa,R., Obata,H., Tagata,N. : Nippon Gomu Kyokaisi, 64, 363 (1991)

56) Simon,G., Schneider,H., Häusler, K. G. : Progr. Colloid Polym. Sci. 78, 30 (1988)

57) Sakano,H., Ikawa,K., Kojima,H. : Kobunshi Ronbunshu, 54, 757 (1997)

58) Nakahama, H. : 14th, Elastomer Con. Preprint, (2001) p.110

59) Matsumoto,Y., Yamada,E., Iwabuki, H., Nagata, K. : $15^{\text {th }}$, Elastomer Con. Preprint, (2002), p.116

60) Wakamatsu,K., Sato,H., Nakahama.H. : 15 $5^{\text {th }}$, Elastomer Con. Preprint, (2002), p.178

61) Ito,M., Kanashima,K., Sawazumi,J., Hori,H. : Nippon Gomu Kyokai Annual Meeting 2002 Preprint, (2002), p.73 